\title{
Practicing Pragmatism During a Pandemic: INDIANA's APPELlate COURTS PRACTICALly APPLY INDIANA'S CONSTITUTION IN 2020
}

\author{
SCOTT CHINN* \\ DANIEL E. PULLIAM** \\ STEPHANIE L. GUTWEIN*** \\ ELIZABETH M. LITTLE ${ }^{* * * *}$
}

Although the last few years produced minimal developments in Indiana constitutional law, ${ }^{1}$ this survey period, the Indiana appellate courts used their constitutional powers to pragmatically address issues associated with the COVID19 pandemic and to clarify the test for constitutional double jeopardy violations.

In 2020, the COVID-19 pandemic and disciplinary proceedings against Indiana's former Attorney General led the Indiana Supreme Court to address three cases concerning its original jurisdiction. The Indiana Supreme Court invoked its original jurisdiction to adopt emergency court rules protecting stimulus payments received under the federal Coronavirus Aid, Relief, and Economic Security ("CARES") Act. But it concluded it did not have original jurisdiction to direct the actions of local prisons and jails as to detained, jailed, and incarcerated individuals whose livelihoods COVID-19 threatened.

And after more than twenty years of occasionally inconsistent results, the Indiana Supreme Court overruled the Richardson constitutional tests for resolving claims of substantive double jeopardy and limited the reach of Indiana's double

* Scott Chinn is a partner at Faegre Drinker Biddle \& Reath LLP practicing public sector law and litigation. B.A. 1991, Indiana University; J.D. 1994, magna cum laude, Indiana University Robert H. McKinney School of Law. He is an adjunct professor at the McKinney School where he teaches Indiana Constitutional Law and former Editor-in-Chief of the Indiana International and Comparative Law Review. He clerked for Judge David F. Hamilton, then District Judge, U.S. District Court, Southern District of Indiana.

** Daniel Pulliam is a partner in the business litigation group at Faegre Drinker Biddle \& Reath LLP. B.A. 2004, cum laude, Butler University, Indianapolis; J.D. 2010, magna cum laude, Indiana University Robert H. McKinney School of Law. He is also a former Editor-in-Chief of the Indiana Law Review and The Butler Collegian and a former law clerk for Judge John Daniel Tinder on the U.S. Court of Appeals for the Seventh Circuit.

*** Stephanie Gutwein is an associate in the business litigation group at Faegre Drinker Biddle \& Reath LLP. B.S. 2010, Indiana University; J.D. 2013, summa cum laude, Indiana University Robert H. McKinney School of Law. She is a former Executive Notes Editor of the Indiana Law Review and extern for the Honorable Judge William T. Lawrence.

**** Elizabeth Little is an associate in the finance and restructuring group at Faegre Drinker Biddle \& Reath LLP. B.A. 2011, Indiana University-Purdue University of Indianapolis; J.D. 2016, summa cum laude, Indiana University Robert H. McKinney School of Law. She is a former Executive Notes Editor of the Indiana Law Review.

1. The authors thank Konstantina Kloufetos for her invaluable assistance in gathering the materials for this article. 
jeopardy clause. ${ }^{2}$ Now, under Wadle v. State, double jeopardy protections extend only to successive prosecutions - not multiple punishments - for the same conduct. ${ }^{3}$ And a statute may permit multiple punishments for multiple victims if the statutory language is conduct- or results-based.

During the survey period, Indiana's appellate courts substantively addressed twelve areas. ${ }^{4}$ As in previous years, the courts regularly issued substantive decisions on government searches and protection of the rights of the accused. Litigants successfully challenged government actions under the openness of courts and excessive bail provisions, lost their challenge under article 8, section 1 to the State's structure of its charter school tuition funding, and were sometimes successful in their search and seizure challenges and challenges based on article 1 , section 13 .

\section{PRIVILEGES AND IMMUNITIES}

In M.C. v. State, ${ }^{5}$ the Indiana Court of Appeals rejected a sixteen-year-old juvenile's assertion that the trial court's granting wardship to the Indiana Department of Correction violated, among other things, his rights under the equal privileges and immunities clause of the Indiana Constitution. Specifically, the juvenile argued that the trial court's order was unconstitutional because it imposed greater restrictions on him than on a similarly situated adult offender and was not substantially related to a sufficiently important government interest. ${ }^{6}$ The court disagreed. It held that the legislature's decision to treat juvenile delinquents differently from adult offenders "is rationally related to the goal of promoting rehabilitation among juvenile delinquents" because certain restrictive placements,

2. Wadle v. State, 151 N.E.3d 227 (Ind. 2020).

3. Id. at $245-46$.

4. The courts addressed eighteen topics in 2014, Jon Laramore \& Daniel E. Pulliam, Indiana Constitutional Developments: Small Steps, 47 IND. L. REV. 1015, 1042 (2014); ten in 2015, Jon Laramore \& Daniel E. Pulliam, Developments in Indiana Constitutional Law: A New Equal Privileges Wrinkle, 48 IND. L. REV. 1223, 1240 (2015); fourteen in 2016, Scott Chinn \& Daniel E. Pulliam, Minimalist Developments in Indiana Constitutional Law-Equal Privileges Progresses Slowly, 49 IND. L. REv. 1003, 2019 (2016); twelve in 2017, Scott Chinn \& Daniel E. Pulliam, Emerging Federal Reliance-Continued State Constitutional Minimalism: Indiana State Constitutional Law Summaries-2015-2016, 50 IND. L. REv. 1215, 1238 (2017); ten in 2018, Scott Chinn \& Daniel E. Pulliam, Emerging Federal Reliance-Continued State Constitutional Minimalism: Indiana State Constitutional Law Summaries-2016-2017, 51 IND. L. REV. 993, 1012 (2018); thirteen in 2019, Scott Chinn, Daniel E. Pulliam, \& Elizabeth M. Little, Stuck in a Rut or Merely Within the Lines? Indiana State Constitutional Law Summaries-2017-2018, 52 IND. L. REV. 689, 711 (2019); and fifteen in 2020, Scott Chinn, Daniel E. Pulliam, \& Elizabeth M. Little, Continued Progressions Toward Irrelevance? Indiana State Constitutional Law Summaries-2018-2019, 53 IND. L. REV. 865, 893 (2021).

5. M.C. v. State, 134 N.E.3d 453 (Ind. Ct. App. 2019), trans. denied, 143 N.E.3d 962 (Ind. 2020).

6. Id. at 460 . 
including the type of wardship that the juvenile was challenging, "can promote rehabilitation and the policy of individual accountability." It also rejected the juvenile's argument that he was treated disparately because he was sent to a Department of Correction facility designed to meet the juvenile's needs, rather than a county jail-as an adult offender might be. ${ }^{8}$ The court found no "meaningful distinction" between these two types of facilities that would support the juvenile's constitutional claim. ${ }^{9}$

\section{SEARCH AND SEIZURE}

In Shorter v. State, ${ }^{10}$ the court of appeals affirmed the denial of a motion to suppress evidence as illegal under the Indiana Constitution based on the trial court's factual findings. First, the court of appeals refused to reweigh the video and testimonial evidence that the trial court found sufficient to show that the defendant's turn signal was on within two hundred feet before making a left turn. ${ }^{11}$ Because of this factual finding, the defendant violated state law requiring turn signals within two hundred feet of the turn or changing lanes, therefore justifying the traffic stop. ${ }^{12}$ Second, the court of appeals affirmed the trial court's finding that the law enforcement officer had sufficient experience and training to detect the odor of burnt synthetic drugs to justify the search of the defendant's vehicle. $^{13}$

In a trio of cases, the court of appeals held that violations of Indiana's laws governing the use of turn signals justified law enforcement stops under article 1, section 11 of the Indiana Constitution.

In Farris v. State, ${ }^{14}$ the court of appeals held that a law enforcement officer's observation of multiple violations of the Indiana code requiring drivers to signal their intention to change lanes at least 200 feet from the change of lanes justified a traffic stop. The defendant pulled from a travel lane to the side of the road to drop a passenger off without using his turn signal. ${ }^{15}$ The defendant then continued onto the street, again without signaling. ${ }^{16}$ At an intersection, less than 200 feet from the drop-off point, the defendant did signal and argued that compliance with Indiana law was impossible given the earlier stop. ${ }^{17}$ The court found that the

7. Id. at 462 (citation omitted).

8. Id.

9. Id.

10. Shorter v. State, 144 N.E.3d 829 (Ind. Ct. App.), trans. denied, 149 N.E.3d 607 (Ind. 2020).

11. Id.

12. Id. at 837 .

13. Id. at 839 .

14. Farris v. State, 144 N.E.3d 814 (Ind. Ct. App.), trans. denied, 149 N.E.3d 609 (Ind. 2020).

15. Id. at 816-17.

16. Id. at 817 .

17. Id. at 821 . 
original sin of failing to signal before dropping the passenger off justified the stop. ${ }^{18}$ Enforcement of traffic laws constituted "a legitimate, if not a compelling, need" and is thus reasonable. ${ }^{19}$

Then, in Alexander v. State, ${ }^{20}$ the court of appeals held that a driver's failure to signal his intent to turn at least 200 feet in advance of the turn, as required by Indiana statute ${ }^{21}$ justified a traffic stop. The statutory violation justified the stop's reasonableness under article 1, section 11's test for stops even though there were no other cars or pedestrians around at the time. Indiana's traffic laws do not depend on "situation-specific factors.".2

Finally, in State v. Davis, ${ }^{23}$ the court of appeals held that an officer's mistaken belief, that failure to signal upon departing a roundabout violated State law, was not objectively reasonable and affirmed the suppression of a digital scale and methamphetamine residue. The court found that when a motorist enters a roundabout, the driver simply follows the road along "the natural flow of the road" similar to a curve in the road. ${ }^{24}$ Signaling upon exiting the roundabout would be "nonsensical," particularly if the driver simply continues "in a continuous lane" and there are no motorists to alert for safety purposes. ${ }^{25}$ When a motorist exits a roundabout, Indiana law fails to specify when the motorist would "turn" or what even constitutes a turn. ${ }^{26}$ Furthermore, most roundabout entrances and exits are much less than the 200 feet required for the timing of the turn signal. ${ }^{27}$ This "square peg . . cannot fit into the roundabout hole." 28

In Byers v. State, ${ }^{29}$ the court of appeals affirmed the denial of a motion to suppress evidence obtained on a search warrant that rested in four-day-old drone video footage showing a woman handling a "small baggie with white powder" and a "cut off straw." The video also identified the defendant handling the drone. $^{30}$ The video was found on the ground in the yard of the defendant's neighbor. ${ }^{31}$ The neighbor took the drone's attached computer hard drive, purchased a reader for the hard drive, and plugged it into her home computer. ${ }^{32}$

18. Id.

19. Id.

20. Alexander v. State, 134 N.E.3d 470 (Ind. Ct. App. 2019), trans. denied, 141 N.E.3d 28 (Ind. 2020).

21. IND. CODE $§ 9-21-8-25$ (2021).

22. Alexander, 134 N.E.3d at 475.

23. State v. Davis, 143 N.E.3d 343 (Ind. Ct. App. 2020).

24. Id. at 347.

25. Id.

26. Id. at 348 .

27. Id.

28. $I d$.

29. Byers v. State, 134 N.E.3d 1051 (Ind. Ct. App. 2019), trans. denied, 141 N.E.3d 807 (Ind. 2020).

30. Id. at 1053 .

31. Id.

32. Id. 
After observing the video, the neighbor turned it over to law enforcement. ${ }^{33}$ Four days after the video's last modified date, law enforcement obtained a search warrant of the defendant's home based on the video. ${ }^{34}$ The court found that the length of time, and the fact that the video only showed one-time possession and consumption of an alleged illegal substance, was not enough to deem the search warrant's probable cause stale. ${ }^{35}$

In Heuring v. State, ${ }^{36}$ the Supreme Court held that affidavits supporting a search warrant were so lacking in indicia of probable cause that the good faith exception to the exclusionary rule did not apply. Warrick County Sheriff's Department officers obtained a warrant to track the defendant's Ford Expedition using a GPS device on the basis that they suspected he was dealing methamphetamine. ${ }^{37}$ But then the GPS device stopped tracking seven days later. ${ }^{38}$ The officers found that the device was missing from the vehicle and, based on the fact that it was still transmitting, filed affidavits for warrants to search the defendant's home and his father's barn for evidence of the device's "theft." 39 Drugs, paraphernalia, and a handgun were found by the officers who then sought a second search warrant to search for narcotics. ${ }^{40}$ During that search, the device was found along with additional contraband. ${ }^{41}$

The Supreme Court readily found that the affidavits lacked facts showing a fair probability that a crime was committed. ${ }^{42}$ Rather, the affidavits showed that someone found a black box attached to their vehicle and removed it. ${ }^{43}$ There was no evidence showing who removed it, and no evidence showed that the device belonged to law enforcement. ${ }^{44}$ These facts showed "nothing more than a tenuous and conclusory suggestion that the tracker was stolen," as they related "exclusively to noncriminal behavior." ${ }^{\prime 4}$ Yet for the evidence from the searches to be suppressed, the defendant needed to show that the officers did not otherwise act in good faith. ${ }^{46}$ The Supreme Court found that reasonably well-trained officers would have known that these facts failed to establish probable cause and did not include facts showing essential elements of the alleged theft. ${ }^{47}$ Applying the exclusionary rule here, in a case "bereft of evidence linking the object of a search

33. Id.

34. Id.

35. Id. at 1056 .

36. Heuring v. State, 140 N.E.3d 270 (Ind. 2020).

37. Id. at 272 .

38. Id.

39. Id.

40. Id.

41. Id. at $272-73$.

42. Id. at 274 .

43. Id. at 275 .

44. Id.

45. Id. at 276.

46. Id.

47. Id. at 277 . 
with the alleged offense," would "deter similar reckless conduct in the future."48

In Atkins v. State, ${ }^{49}$ the court of appeals held that even though a law enforcement officer informed the defendant that he could "say no" to a request to search a backpack for weapons, "request a warrant, or ask for a lawyer if you want," the defendant's Pirtle rights were violated because he was not later advised of his rights to a lawyer when he was in custody. ${ }^{50}$ Under Pirtle v. State, law enforcement must advise a person in police custody of the right to the presence and advice of counsel before consenting to a search, and the arrested person must explicitly waive that right. ${ }^{51}$ Here, the original statement regarding the right to ask for a lawyer was made before the defendant was in custody and was merely regarding the search of the backpack for weapons. ${ }^{52}$ Upon opening the backpack, the law enforcement officer observed a set of computer equipment suspected to be subject to the theft the officer was investigating. ${ }^{53}$ Law enforcement then restrained the defendant by ordering him to sit on the ground and further sought his permission to review the computer equipment. ${ }^{54}$ After some resistance, the defendant finally relented. ${ }^{55}$ Because law enforcement failed to explicitly inform the defendant that he had a right to counsel before consenting to the search of the computer equipment, as opposed to the backpack for weapons, the court of appeals found that the evidence of the computer equipment should be suppressed. ${ }^{56}$

\section{OPENNESS OF COURTS}

In Harris v. State, ${ }^{57}$ the court of appeals held that the trial court violated due process under the U.S. Constitution and the Indiana Constitution by barring a juvenile defendant's mother from being present during his attempted murder trial because of a separation of witnesses order. Under the code governing juvenile offenses, a parent is deemed a party to the proceedings and has all rights provided under the Indiana trial rules.$^{58}$ Here, however, because Harris was waived to adult criminal court, the juvenile code granting his parents party status in the juvenile proceeding no longer applied. ${ }^{59}$ The court's analysis rested on Indiana Evidence

48. Id. at 278 (citing Dolliver v. State, 598 N.E.2d 525, 529 (Ind. 1992)).

49. Atkins v. State, 143 N.E.3d 1025 (Ind. Ct. App.), trans. denied, 150 N.E.3d 1019 (Ind. 2020).

50. Id. at 1035 .

51. Pirtle v. State, 323 N.E.2d 634, 640 (Ind. 1975).

52. Atkins, 143 N.E.3d at 1034-35.

53. Id. at 1034.

54. Id.

55. Id.

56. Id. at 1035 .

57. Harris v. State, 148 N.E.3d 1107 (Ind. Ct. App.), trans. granted, 153 N.E.3d. 1092 (Ind. 2020).

58. Id. at 1111-12.

59. Id. at 1112 . 
Rule 615, which allows a court to insulate any witness from the testimony of other witnesses upon request of any party. ${ }^{60}$ But the rule does not authorize excluding "a person whose presence a party shows to be essential to presenting the party's claim or defense." 61

The court turned to U.S. Supreme Court holdings recognizing a juvenile defendant's "special status." ${ }^{2}$ Children lack maturity and have an underdeveloped sense of responsibility. ${ }^{63}$ Because children are not miniature adults, they have a special status in criminal procedure ${ }^{64}$ Regardless of the defendant's status in adult court, "our criminal procedures should take into account the juvenile's youth and need for such meaningful consultation with a parent, especially during a trial." ${ }^{\prime 65}$ Thus, excluding the defendant's mother constituted an error under the rules of evidence. ${ }^{66}$ The court also found that the error was not harmless even though the evidence at trial was persuasive. ${ }^{67}$ The opportunity for a sixteen-year-old to have a parent present at trial "cannot readily be quantified"; not only did the State fail to make a harmless error argument on appeal, the State failed to even call the mother as a witness to testify even though the State's inclusion of her on the witness list resulted in her exclusion from the trial in the first place. ${ }^{68}$

In Watson v. State, ${ }^{69}$ the court of appeals vacated Watson's habitual offender status because the State violated his speedy trial rights. A jury convicted Watson of two drug offenses in 2001, and then another jury adjudicated him to be a habitual offender based on convictions from 1990, 1992, and $1997 .^{70}$ The trial court sentenced him to fifty years for the drug offenses and an additional thirty years for the habitual offender adjudication. ${ }^{71}$ In 2012, the trial court vacated the habitual offender adjudication because the underlying convictions could not form the basis of the adjudication. ${ }^{72}$ The State amended the charge by basing it on

60. Id. at 1111 .

61. Id. at 1112 (quoting IND. R. EvID. 615).

62. Id. (citing Miller v. Alabama, 567 U.S. 460, 465 (2012); J.D.B. v. North Carolina, 564 U.S. 261, 277 (2011); Graham v. Florida, 560 U.S. 48, 82 (2010); Roper v. Simmons, 543 U.S. 551 (2005)); but see Jones v. Mississippi, 141 S. Ct. 1307 (2021) (states have discretionary power to sentence juvenile offenders to life without parole even without separate finding of incorrigibility, sustaining conviction of juvenile who was fifteen at time of offense).

63. Id. at 1113 .

64. Id.

65. Id. at 1114.

66. Id.

67. Id. at $1114-15$.

68. Id.

69. Watson v. State, 135 N.E.3d 982 (Ind. Ct. App. 2019), vacated, 143 N.E.3d 945 (Ind. 2020).

70. Id. at 983 .

71. Id.

72. Id. at 984 . 
convictions from 1972, 1977, and 1981. ${ }^{73}$ Starting in 2013, hearings were continued, special judges were appointed, and Watson changed counsel. ${ }^{74}$ In 2018, the trial court denied Watson's motion to dismiss for violation of his speedy trial rights under Rule 4(C) of the Indiana Rules of Criminal Procedure; the court concluded that just less than four years of delay were attributable to the State or the court but that Watson, and the withdrawal of his original counsel, bore responsibility for the remainder of the delay. ${ }^{75}$

The court of appeals recognized that Rule 4(C) establishes more rigorous time limits than the federal constitutional guarantee of a speedy trial by requiring criminal charges to be brought within one year. ${ }^{76}$ Even though Watson had already been convicted of the underlying drug offenses, the court of appeals found that Rule 4(C)'s broad language applies to criminal defendants in various situations. ${ }^{77}$ Although the State and the court bore responsibility for nearly four years of delay and Watson had to answer for the habitual offender charge while in prison, the record provides little clarity regarding the State's delay in conducting a rehearing that took less than one hour. ${ }^{78}$ The court recognized that Rule 4(C) imposes stronger protections than the U.S. Constitution's Sixth Amendment, but it never once invoked Indiana's own provision for speedy justice. $^{79}$

Judge Kirsch dissented on the basis that Rule 4(C) only applies to persons "held to answer a criminal charge for a period greater tha[n] one year" and that the period runs from the date of the defendant's arrest or the filing of a criminal charge. ${ }^{80}$ Because both dates expired more than a decade before Watson sought relief, Watson sought multiple continuances of his hearing, and the hearing rested on evidence of criminal charges and not witness recollections, Judge Kirsch would have affirmed the trial court. ${ }^{81}$

In Dilley v. State ${ }^{82}$ the court of appeals reversed a conviction because the trial court granted a motion for continuance without a showing by the State that reasonable efforts were made to obtain delayed laboratory test results. The prosecutor had failed to inform the trial court that the evidence had yet to be sent to the laboratory for testing and that was only done after the State filed a written motion for continuance suggesting that the testing was already underway. ${ }^{83}$

73. Id.

74. Id. at $984-85$.

75. Id. at $985-86$.

76. Id. at 986 .

77. Id. at 987.

78. Id.

79. Id. at 986.

80. Id. at 988 (Kirsch, J., dissenting).

81. Id.

82. Dilley v. State, 134 N.E.3d 1046 (Ind. Ct. App. 2019).

83. Id. at 1050 . 


\section{RIGHTS OF THE ACCUSED AND VICTIMS}

In Moore v. State, ${ }^{84}$ the court of appeals affirmed a conviction despite the fact that the arresting officer refused to answer the defendant's questions regarding what charges he faced. Article 1, section 13 states that the accused has a right to demand and have a copy of the charges they are facing, but that right does not apply at the arrest stage. ${ }^{85}$ Rather, case law has interpreted this provision to apply at an initial hearing in court. ${ }^{86}$ Here, the defendant was initially given information by law enforcement that suggested that they suspected him of helping his father dispose of the defendant's stepmother, involvement that the defendant denied. ${ }^{87}$ Then days later, law enforcement re-interviewed the defendant after serving him with an arrest warrant and after the father had confessed to the killing, but the arresting officer only told him that the father had confessed as the defendant asked repeatedly for the charging information. ${ }^{88}$

Even though the arresting officer provided the defendant with evasive answers regarding the charges he faced, and only provided the information after he had made incriminating statements, he nevertheless received a hearing. ${ }^{89}$ That said, the court did not address the near two-year gap of time between the request for the charging information in 2015 and the initial hearing in $2017 . .^{90}$ The court simply found that because the constitutional text did not specifically state that the arresting officer had to provide the charging information, providing the charging information two years later was sufficient for the defendant to prepare his defense. ${ }^{91}$

In Matter of Br.B., ${ }^{92}$ the court of appeals reaffirmed that children in need of services proceedings, known as "CHINS" proceedings, are not criminal proceedings that entitle parents to the constitutional right to be tried in the county in which the offense is committed. Although the State is required to prove venue, it may be established by a preponderance of the evidence and need not be proven beyond a reasonable doubt. ${ }^{93}$

In Easler v. State, ${ }^{94}$ the Indiana Supreme Court held that a trial court's failure to allow defense counsel the opportunity to challenge a juror's service for cause, where the juror had informed the trial court that a family member was killed by a drunk driver, constituted an abuse of discretion. The defendant was on trial for

84. Moore v. State, 143 N.E.3d 334 (Ind. Ct. App.), trans. denied, 149 N.E.3d 605 (Ind. 2020).

85. Id. at 340-41 (citing IND. Const. art. $1, \S 13$ ).

86. Id.

87. Id. at 337.

88. Id. at 337-38.

89. Id. at 338,341 .

90. See id. at 337-38.

91. Id. at 340-41.

92. M.B. v. Ind. Dep't of Child Servs., 139 N.E.3d 1066 (Ind. Ct. App. 2019).

93. Id. at 1071.

94. Easler v. State, 131 N.E.3d 584 (Ind. 2019). 
operating a vehicle while intoxicated. ${ }^{95}$

The Court found the right to a fair trial before an impartial jury a cornerstone of the criminal justice system guaranteed by the Indiana and federal constitutions. ${ }^{96}$ Here, the juror had been selected but not sworn in when she submitted a note that a family member was killed by a drunk driver before she was born, changing her family dynamic forever. ${ }^{97}$ Instead of allowing defense counsel to question the juror further, the court indicated that there was nothing to be done. ${ }^{98}$ The Supreme Court found that the note qualified as the basis to establish possible bias after defense counsel asked for a hearing on the matter. ${ }^{99}$ Even though the juror had included in the note her belief that she could be a jury member and "be fair and impartial," her potential bias had not been wiped away. ${ }^{100}$ Because of the passage of time, the risk of testimony about the jury's deliberations, and concerns for juror harassment, the Court rejected the State's request to simply hold a hearing on the juror's potential bias and ordered a new trial. ${ }^{101}$

In Wiley v. State, ${ }^{102}$ the court of appeals reversed a bench trial misdemeanor conviction for operating a vehicle without a court-ordered ignition interlock device. At his initial hearing, the defendant signed an advice of rights form that indicated that he had to file a written demand for a jury trial at least ten days before the trial setting. ${ }^{103}$ A month later, the defendant's appointed counsel orally requested a jury trial. ${ }^{104}$ At trial, the defendant asked his counsel to withdraw. ${ }^{105}$ The court thus re-set the jury trial on the condition that the defendant pay for the costs of assembling a jury pool. ${ }^{106}$ At the second trial setting, the prosecutor moved to strike the jury trial because the defendant was only charged with misdemeanors, and he never filed the written request for a jury trial. ${ }^{107}$ The court agreed, and the defendant was convicted at a bench trial over the defendant's demands for a jury trial. ${ }^{108}$

The court of appeals found that the fundamental right to a jury trial, as provided for in the Indiana and federal constitutions, requires a waiver of the right to be knowing, intelligent, and voluntary. ${ }^{109}$ Because the defendant was charged

\footnotetext{
95. Id. at 586 .

96. Id. at 588 .

97. Id. at 586-87.

98. Id. at 587 .

99. Id. at 590-91.

100. Id. at 590 .

101. Id. at 591-92.

102. Wiley v. State, 150 N.E.3d 710 (Ind. Ct. App. 2020).

103. Id. at 712 .

104. Id.

105. $I d$.

106. $I d$.

107. Id. at 713 .

108. Id.

109. Id. at 714 .
} 
with misdemeanors, he still had to demand that jury trial. ${ }^{110}$ Here, although a timely written request for a jury trial was not made, the defendant nevertheless persistently sought and demanded a jury trial through his court-appointed counsel and later by agreeing to pay for the expenses of assembling the jury pool. ${ }^{111}$ This led the defendant to believe that the "necessary steps" to ensure a jury trial had been taken and that nothing else needed to be done. ${ }^{12}$ Given that the implied waiver of a right to a jury was not knowing, based on the failure to comply with the rules governing written demands for a jury within ten days of the trial date, the court of appeals found any waiver invalid. ${ }^{113}$

In C.J. v. State ${ }^{114}$ the court of appeals reversed the trial court's adjudication of a twelve-year-old juvenile as a delinquent. At the initial interrogation of the juvenile, the detective reviewed the waiver of rights form with the juvenile and his mother. ${ }^{115}$ After acknowledging they understood the waiver, the juvenile and his mother consulted in private for just over two minutes before returning to the interrogation room. ${ }^{116}$ After the juvenile confirmed he wanted to speak with the detective without his mother present, the juvenile admitted the allegations. ${ }^{117}$ At the delinquency hearing, the detective testified as to the juvenile's admission. ${ }^{118}$ The mother testified that even though they signed the waiver form at the interrogation, the juvenile did not understand the rights on the form. ${ }^{119}$ Based on the juvenile's testimony, the court adjudicated the juvenile as a delinquent. ${ }^{120}$

In his appeal, the juvenile argued that the trial court abused its discretion in admitting evidence collected during his interrogation because his waiver of his privilege against self-incrimination was not knowing and voluntary. ${ }^{121}$ Before juvenile interrogations may be used in court, Indiana Code section 31-32-5-1(a) "requires additional procedural safeguards beyond" what is required under Miranda v. Arizona, the Fifth Amendment to the United States Constitution, the Due Process Clause of the Fourteenth Amendment, and article 1, section 14 of the Indiana Constitution, including that the juvenile and his guardian "knowingly, intelligently, and voluntarily waive the juvenile's rights." ${ }^{22}$ In determining whether a juvenile knowingly, intelligently, and voluntarily waived his rights, courts look at the totality of the circumstances and consider

110. Id.

111. Id.

112. Id.

113. Id. at 715 .

114. C.J. v. State, 141 N.E.3d 830 (Ind. Ct. App.), trans. denied, 149 N.E.3d 605 (Ind. 2020).

115. Id. at 833 .

116. Id.

117. Id. at 834 .

118. Id.

119. Id.

120. Id.

121. Id. at 835 .

122. Id. 
the juvenile's physical, mental, and emotional maturity; whether the juvenile or his parent understood the consequences of speaking with law enforcement; whether the juvenile and his parent were informed of the delinquent act for which the juvenile was suspected; the length of time the juvenile was held in custody before consulting with his parent; whether law enforcement used any force, coercion, or inducement; and whether the juvenile and his parents had been advised of the juvenile's Miranda rights. ${ }^{123}$

Here, the court of appeals found that the State failed to meet its burden in showing that the juvenile's waiver met this requirement "because of [the juvenile's] demonstrated lack of maturity, the fact that he was not advised of the crime and possible consequences, and his minimal consultation with [his m]other." 124 Accordingly, the court held that the trial court erred in admitting the evidence of the juvenile's interrogation. ${ }^{125}$

\section{ARTICLE 1, SECTION 16 - EXCESSIVE BAIL}

In Yeager v. State ${ }^{126}$ the court of appeals reversed a trial court's refusal to reduce a defendant's $\$ 250,000$ cash-only bail on charges that he battered the twoyear-old son of his girlfriend. On appeal, the court found that the trial court abused its discretion by failing to recognize the defendant's lack of criminal history (besides underage drinking), his stable life and employment, and a good relationship with his family. ${ }^{127}$ Under article 1, section 16, decisions on the excessiveness of bail turn on (1) the object of bail, and (2) the accused's financial ability to put up that bail amount. ${ }^{128}$ Here, although the State had sufficient evidence to bring the charges, the fact that the defendant was accused did not constitute the clear and convincing evidence necessary to establish that he was a danger to the community. ${ }^{129}$

\section{DOUBLE JEOPARDY}

Indiana courts have long used a two-part test to determine whether the Indiana Constitution's prohibition against double jeopardy is violated. First, the courts look at whether the offenses share statutory elements and then, whether the actual evidence used to establish a conviction on one count was also used to establish an element of a separate count. But in Wadle v. State, ${ }^{130}$ the Indiana Supreme Court expressly overruled what had become known as the Richardson

123. Id. at 836 (citation omitted).

124. Id. at 837 .

125. $I d$. at 838 .

126. Yeager v. State, 148 N.E.3d 1025 (Ind. Ct. App. 2020).

127. Id. at 1028 .

128. Id. at 1027 .

129. Id. at 1028-29.

130. Wadle v. State, 151 N.E.3d 227 (Ind. 2020). 
constitutional tests in resolving claims of substantive double jeopardy.

Under Richardson v. State, Indiana courts applied double jeopardy principles as a constitutional matter to two issues: multiple (or "successive") prosecutions for the "same offense" and multiple punishments for the "same offense." 131 To determine whether multiple punishments were imposed for the "same offense," Richardson instructed courts to examine whether the same "actual evidence" was used to obtain multiple convictions. ${ }^{132}$ Now under Wadle, article 1, section 14's double jeopardy clause "protects only against successive prosecutions for the same offense." 133

Historically, the clause's phrase "same offense" barred successive prosecutions for the same offense. Criminal codes defined few offenses, and pleading rules barred multiple convictions in a single trial. ${ }^{134}$ But as statutory law expanded, defining additional and more complex criminal offenses, and pleading rules relaxed, multi-count indictments increased the possibility of multiple convictions or punishments for the "same offense."135 The "statutory elements test" has been widely used, and adopted by the United States Supreme Court, to compare the statutory elements of offenses to determine whether multiple offenses are the "same." 136 The question asks: where the same act or transaction violates two distinct statutes, does each statute require proof of a single fact that the other statute does not require? ${ }^{137}$ The "actual evidence test" instead looks at what evidence the prosecution presented at trial. ${ }^{138}$ This test, adopted in Richardson more than twenty years ago, allowed for analytical flexibility, but also led to inconsistent results and at times illogical results in complex criminal enterprise cases but also injustices in simple burglary and theft cases. ${ }^{139}$ This "patchwork" of conflicting precedent prompted the Court to simply overrule the test and propose a new path forward. ${ }^{140}$

The Supreme Court started by holding that the double jeopardy clause only protects against successive prosecutions for the same conduct, not multiple punishments for the same conduct. ${ }^{141}$ Double jeopardy protects against repeated attempts by the government to punish an accused and minimizes the risk of wrongful conviction upon retrial. ${ }^{142}$ Although there is potential harm caused by multiple punishments for the same conduct, statutory, common law, and other constitutional protections better provide that protection than double jeopardy

131. Richardson v. State, 717 N.E.2d 32, 67 (Ind. 1999) (Boehm, J., concurring).

132. Id. at 68 .

133. Wadle, 151 N.E.3d at 245.

134. Id. at 238 .

135. Id.

136. Id. at 239 .

137. Id.

138. Id.

139. Id. at 241.

140. Id. at 244 .

141. Id. at 245.

142. Id. 
doctrine. ${ }^{143}$ "Lesser-included offense[s], . . two offenses consisting of the same act, ... [an] offense consisting of the same act as an element of another offense, ... elevat[ing] an offense imposed for the same "behavior or harm," and a conspiracy for the same act as another offense all remain bars to conviction and punishment. ${ }^{144}$

Nevertheless, when a single criminal act or transaction violates multiple statutes with common elements, multiple convictions may be obtained if the statutory language expressly "or by unmistakable implication" permits more than one conviction. ${ }^{145}$ But if the statute does not expressly permit multiple convictions, courts must apply the included-offense statutes, which prohibit convictions for both an offense and an "included offense." included in another offense, the court must determine whether the facts of the two crimes are the same. ${ }^{147}$ If the facts are different, there is no double jeopardy violation, but if the offense is one continuous offense, the multiple charges may only be included as alternatives as opposed to cumulative charges. ${ }^{148}$

In the case before the Supreme Court, two of the offenses violated double jeopardy because the statutes criminalizing (1) OWI endangering a person, and (2) OWI with a blood-alcohol concentration above 0.08 did not permit cumulative punishment, the second offense was included in the offense of the former, and there was no dispute that the facts were other than the same. ${ }^{149}$ The statutes behind the two other convictions, (1) leaving the scene of an accident, and (2) OWI causing serious bodily injury, also did not authorize multiple punishments and were lesser-included offenses. ${ }^{150}$ And the facts showed that the defendant physically attacked and then ran the victim over with his car in one "seamless string of events." 151 Because these actions were a single "continuous transaction," the Court found that a conviction for both offenses violated double jeopardy principles even under the new test. ${ }^{152}$

In a companion case, Powell v. State,${ }^{153}$ the Supreme Court addressed when a single criminal act or transaction violates a single statute, and held that a defendant who fired five or six shots in rapid succession at two victims, seriously injuring one of them, may be convicted for two counts of attempted murder. The attempted-murder statute does not contain clear units of prosecution-it punished a single course of criminal conduct and not certain discrete acts or "successive,

143. Id. at 246 .

144. Id. at 246-47 (quoting Richardson v. State, 717 N.E.2d 32, 55-56 (Ind. 1999) (Sullivan, J., concurring)).

145. Id. at 235.

146. Id. at 248 .

147. Id.

148. Id. at 249.

149. Id. at 253.

150. Id. at 254 .

151. Id.

152. Id. at 255 .

153. Powell v. State, 151 N.E.3d 256 (Ind. 2020). 
similar occurrences." 154 Nevertheless, a statute may permit multiple punishments for multiple victims if the statutory language is conduct-based or results-based. ${ }^{155}$ Conduct-based statutes punish certain actions, for example driving, with the presence of certain circumstances such as intoxication. ${ }^{156}$ The focus of these types of offenses is the action, not the consequences, and therefore multiple consequences will not establish multiple offenses ${ }^{157}$ But results-based statutes are defined by actions and the actions' consequences. ${ }^{158}$ Murder or manslaughter focuses on the result - the death of a person. ${ }^{159}$ The "crime is complete" because of the result, provided the mental state is also present. ${ }^{160}$ Crimes defined by consequences thus allow multiple convictions when there are multiple consequences from the same criminal act. ${ }^{161}$

But attempted murder is, by definition, not consequence-based. ${ }^{162}$ Yet the statute also contemplates a single victim. ${ }^{163}$ Thus, when multiple victims are involved in the same action, multiple results could be contemplated. ${ }^{164}$ Because the statutory text pointed in both directions, the Court found the language ambiguous. ${ }^{165}$ Thus, the statute permits only single prosecutions unless the facts showed distinguishable offenses. ${ }^{166}$ Here, the defendant's actions indicated two different offenses because the evidence showed that the defendant knew there were two people occupying the vehicle that he fired five or six times into. ${ }^{167} \mathrm{He}$ did not fire blindly into a group of individuals. ${ }^{168}$ Rather, with his victims mere feet away, he directly engaged both victims in gunfire. ${ }^{169}$

\section{RIGHT TO BEAR ARMS}

In Gammons v. State, ${ }^{170}$ the Indiana Supreme Court reversed the defendant's guilty verdict and remanded for a new trial after finding the trial court's selfdefense jury instruction was not a correct statement of law. At the defendant's trial for attempted murder and carrying a handgun without a license, the

154. Id. at 264-65 (citation omitted).

155. Id. at 265 .

156. Id. at $265-66$.

157. Id. at 266 .

158. Id.

159. Id.

160. Id.

161. Id.

162. Id.

163. Id. at 267.

164. Id.

165. Id. at 268.

166. Id.

167. Id. at 270 .

168. Id.

169. Id.

170. Gammons v. State, 148 N.E.3d 301 (Ind. 2020). 
defendant, while conceding that he was carrying a handgun without a license, asserted he acted in self-defense. ${ }^{171}$ Based on Indiana Code section 35-41-3-2, the trial court instructed the jury that the defendant could not assert self-defense to the attempted murder charge if he was "committing a crime that [wa]s directly and immediately related to the confrontation." 172

The Supreme Court found that such jury instruction "was an imprecise statement of law," finding that while the statutory language

instructs that a person cannot use force defending himself if he, among other things, "is committing . . . a crime," . . . we do not strictly apply that statute because " $[t]$ the legislature is presumed to have intended the language used in the statute to be applied logically and not to bring about an unjust or absurd result." 173

Instead, the Court held that "self-defense is barred only when there is 'an immediate causal connection between the crime and the confrontation." "'174 Because the Court remanded the case based on the statutory language, it declined to analyze the defendant's argument that his right to bear arms for self-defense under article 1, section 32 of the Indiana Constitution was infringed. ${ }^{175}$

\section{ARTICLE 2, SECTION 1 - ELECTIONS}

In Kite v. Curlin, ${ }^{176}$ the court of appeals considered a former school board member's post-election challenge to a candidate's election to a county school board on the basis that the elected board member failed to satisfy the statutory residency requirements to serve on the board and therefore was ineligible to hold the board seat. The court first confirmed that Indiana Code section 3-12-8 authorizes post-election challenges to an elected candidate's eligibility for the office. ${ }^{177}$ Next, it confirmed the trial court's determination that the elected board member failed to meet the statutory residency requirements for serving on the board at the time that she was elected. ${ }^{178}$ It then turned to the trial court's

171. Id. at 302 .

172. Id. at 303 (alteration in original) (citation omitted).

173. Id. at 304 (alteration in original).

174. Id. at 304-05.

175. Id. at 304 n.2. The court of appeals had found that the trial court's instruction did not violate article 1, section 32 of the Indiana Constitution because "the right to bear arms is not absolute. Our court has held that 'the core value embodied by Section 32 is the right for lawabiding citizens to bear arms for self defense.' . . Gammons was not a law-abiding citizen when he shot Gilbert, given that he was illegally carrying a handgun." Gammons v. State, 136 N.E.3d 604, 613 n.8 (Ind. Ct. App. 2019), trans. granted, opinion vacated, 141 N.E.3d 25 (Ind.), vacated, 148 N.E.3d 301 (Ind. 2020).

176. Kite v. Curlin, 139 N.E.3d 1113 (Ind. Ct. App. 2019), trans. denied, 145 N.E.3d 121 (Ind. 2020).

177. Id. at $1120-21$.

178. Id. at $1122-23$. 
conclusion that the candidate's statutory ineligibility was "merely a 'technical' issue" that should not disqualify her from the board. ${ }^{179}$

The court recognized that "Indiana law strongly disfavors 'post-hoc disenfranchisement of voters" and acknowledged the Indiana Supreme Court's instruction in White v. Indiana Democratic Party ex rel. Parker" 180 that "the will of the people in the choice of public officers may not be defeated by any merely formal or technical objections." ${ }^{" 181}$ However, the court distinguished White and Burke v. Bennett ${ }^{182}$ because, in both cases, "the disqualifications at issue had ceased to exist by the time the winning candidate had been elected and assumed office." "183 Finding no apposite Indiana precedent, the court agreed with the Kansas Supreme Court that "the question of whether a candidate is ineligible for office due to her [continued] failure to meet a residency requirement is not a mere formal or technical objection" that should be overlooked post-election, "simply because the ineligibility could have been discovered prior to the election." 184 The court therefore reversed the trial court's decision upholding the candidate's election to the school board and remanded the action for proceedings consistent with the court's opinion. ${ }^{185}$

\section{ARTICle 4, SECTION 1 - GENERAL ASSEMBLY}

In City of Bloomington Board of Zoning Appeals v. UJ-Eighty Corp., ${ }^{186}$ a property owner disputed the propriety of a City of Bloomington zoning ordinance that permitted certain real property to be used as a fraternity or sorority house but, by definition, limited qualifying fraternities and sororities to, among other things, only those that Indiana University had sanctioned or recognized. The property owner argued that the zoning ordinance violated article 4, section 1 of the Indiana Constitution because it unlawfully delegated the City of Bloomington's zoning authority to the university. ${ }^{187}$ The Indiana Supreme Court agreed with the property owner that, under article 4, section 1, "[o]nly Bloomington through its legislative body - acting pursuant to powers granted by the General Assembly — can make or amend its zoning laws." ${ }^{188}$ But it held that Bloomington, not the university, exercised its zoning authority to define fraternities and sororities in the ordinance, and it rejected the property owner's argument that Bloomington had improperly delegated any of that zoning authority to Indiana

179. Id. at 1123 .

180. White v. Ind. Democratic Party ex rel. Parker, 963 N.E.2d. 481 (Ind. 2012).

181. Kite, 139 N.E.3d at 1123 (emphasis omitted) (quoting White, 963 N.E.2d. at 486).

182. Burke v. Bennett, 907 N.E.2d 529 (Ind. 2009).

183. Kite, 139 N.E.3d at 1126.

184. Id. at 1124, 1126 (citing In re Massey, 605 P.2d 147, 150 (Kan. 1980)).

185. Id. at 1127 .

186. City of Bloomington Bd. of Zoning Appeals v. UJ-Eighty Corp., 163 N.E.3d 264 (Ind. 2021).

187. $I d$. at 266 .

188. Id. at 267. 
University merely by defining fraternities and sororities, in part, based on their relationship with the school. ${ }^{189}$

In Tyus v. Indianapolis Power \& Light Co. ${ }^{190}$ a family appealed the trial court's dismissal of their negligence claim against an electric utility subject to the Indiana Utility Regulatory Commission's ("IURC") jurisdiction, based on language in the utility's IURC-approved tariff, which purported to release the utility from liability "for damages resulting . . . to third persons, from the use of electricity, interruption of service or supply, or the presence of the [utility]'s property on [its c]ustomer's premises, unless due to [the utility's] willful default or neglect." ${ }^{" 191}$ On appeal, the family asserted, among other things, that the IURC exceeded its delegated authority when it "approv[ed] . . language purporting to relieve [the utility] of liability for common law tort injuries to a noncustomer, when that injury occurs during [the utility]'s interruption in the supply of electricity." 192

The court of appeals first rejected the utility's assertion that the family had failed to preserve its constitutional argument for appeal because the family's counsel had raised the argument before the trial court during a hearing on the utility's dispositive motion. ${ }^{193}$ The court next rejected the utility's argument that the family was obligated to follow the statutory procedure for appealing the IURC's approval of the tariff, which, among other things, deprives trial courts of subject-matter jurisdiction over the tariff disputes and limits the time within which the disputes may be brought. ${ }^{194}$ It held that because the family was pursuing a common law tort action against the utility, not appealing the utility's tariff under the statute, and the utility had opened its tariff to a constitutional attack by asserting it as an affirmative defense, the family's action was not untimely, and the trial court had jurisdiction over it. ${ }^{195}$ The court then rejected the utility's contention that the court should refer the family's constitutional challenge to the tariff's release provision to the IURC under the doctrine of primary jurisdiction. ${ }^{196}$ The court observed that the doctrine of primary jurisdiction is prudential, not jurisdictional, and found it inapplicable to the family's suit, which, it reiterated, asserted common law tort claims, not an appeal of the utility's approved tariff. ${ }^{197}$

After finding that the family's negligence claim could not be dismissed as a matter of law, the court turned to the family's claim that the IURC's approval of the tariff's release provision "was unconstitutional because it exceeded the

189. Id. at 267-68.

190. Tyus v. Indianapolis Power \& Light Co., 134 N.E.3d 389 (Ind. Ct. App. 2019), trans. denied, 160 N.E.3d 512 (Ind. 2020).

191. Id. at 397 (emphases omitted).

192. Id. at 399.

193. Id.

194. Id. at 400 .

195. Id. at 400-01.

196. Id. at 401 .

197. Id. at 401-02. 
powers delegated to it by the Indiana General Assembly."198 The court confirmed that an administrative agency's authority is defined by statute, and while the legislature may, with sufficient guideposts, delegate to the agency rule-making authority, the legislature cannot, in defining the agency's authority, delegate to it the authority to make law. ${ }^{199}$ The court held that because no statute authorized the IURC "to shield [electric utilities] from liability for injuries caused by [the utilities'] negligence to noncustomers," the IURC was without statutory authority "to approve the [release clause in the utility's tariff], which granted [the utility] immunity for its future negligent actions." 200 Because the IURC lacked the statutory authority to approve that provision in the utility's tariff, the court held that the provision was ultra vires and void. ${ }^{201}$

\section{ARTICLE 7, SECTION 4/6 - ORIGINAL JURISDICTION}

In Matter of Hill, ${ }^{202}$ the Indiana Supreme Court denied the Governor's emergency motion to intervene in disciplinary proceedings pending against Indiana's former Attorney General. In so doing, the Court confirmed that attorney discipline cases under Indiana Admission and Discipline Rule 23 invoke the Indiana Supreme Court's original jurisdiction pursuant to article 7, section 4 of the Indiana Constitution. ${ }^{203}$

Twice, the Indiana Supreme Court addressed requests that it use its original jurisdiction over Indiana's courts' practices and procedures to exercise its emergency rulemaking power to assist Hoosiers affected by the 2019 novel coronavirus ("COVID-19").

In In re Indiana Supreme Court to Engage in Emergency Rulemaking to Protect CARES Act Stimulus Payments from Attachment or Garnishment from Creditors ${ }^{204}$ the Indiana Supreme Court invoked its original jurisdiction in "supervision of the exercise of jurisdiction by the other courts of the State and issuance of writs necessary or appropriate in aid of its jurisdiction" under article 7, section 4 of the Indiana Constitution. The Indiana Supreme Court proceeded to adopt emergency rules protecting from garnishment stimulus payments that judgment-debtors received under $\S 2201$ of the federal CARES Act, except in limited circumstances. ${ }^{205}$ Justice Slaughter dissented from the Court's opinion, concluding that, under the guise of emergency rulemaking, the Court was "overstep[ping its] limited role under Indiana's constitution - which is to interpret law, not make it," and should have left "to the political branches the prerogative

198. Id. at 404.

199. Id. at 405-06.

200. Id. at 406-07.

201. Id. at 408.

202. In re Hill, 144 N.E.3d 200 (Ind. 2020).

203. Id.

204. In re Ind. Supreme Court to Engage in Emergency Rulemaking to Protect CARES Act

Stimulus Payments, 142 N.E.3d 907 (Ind. 2020).

205. Id. 
of deciding and implementing policy." ${ }^{206}$

In Matter of Petition Requesting Indiana Supreme Court to Engage in Emergency Rulemaking to Address Issue of Imprisoned Persons \& COVID-19 Crisis ${ }^{207}$ the Indiana Supreme Court rejected the American Civil Liberties Union's ("ACLU") petition that the Court request the Indiana Department of Correction and county sheriffs take certain actions with respect to detained, jailed, and incarcerated persons in Indiana whose livelihood was threatened by COVID19. The Court held that because the petition sought the Court to direct actions of non-court entities, it did not invoke the Court's original jurisdiction in "supervision of the exercise of jurisdiction by the other courts of the State and issuance of writs necessary or appropriate in aid of its jurisdiction" under article 7 , section 4 of the Indiana Constitution. ${ }^{208}$

\section{ARTICLE 8, SECTION 1 - COMMON SCHOOL SySTEM}

In State v. Indiana Connections Academy, Inc. ${ }^{209}$ several charter schools and their organizers sued the State of Indiana for funds they contended the State owed them for the schools' first operational semester. At the time each of the charter schools began operating, the statutory scheme for funding public schools, including charter schools, provided that Indiana's Department of Education would distribute tuition support funding to the school for a given school year on a monthly basis, beginning in January of the following year. ${ }^{210}$ Thus, while schools would begin their school year in August, the State would distribute tuition support funding for the August-through-December semester at the beginning of the school's second semester, in January of the following year. ${ }^{211}$ And the amount of funding the State would distribute in January was based on the school's attendance numbers from the previous September. ${ }^{212}$ Consequently, while the charter schools began their school year operations in September, they did not receive state tuition funding (based upon the school's September headcount) until the following January. ${ }^{213}$ When the General Assembly amended the school-funding statutes in 2013, it did not address this gap in funding that the charter schools had experienced during their first semester of operations. ${ }^{214}$ Believing that the State was obligated to compensate them for their first six months of operations, the schools sued the State for, among other things, breach

206. Id. at 909 (Slaughter, J., dissenting).

207. In re Petition Requesting Ind. Supreme Court to Engage in Emergency Rulemaking to Address Issue of Imprisoned Persons \& COVID-19 Crisis, 142 N.E.3d 911 (Ind. 2020).

208. Id.

209. State v. Ind. Connections Acad., Inc., 132 N.E.3d 503 (Ind. Ct. App. 2019), trans. denied, 143 N.E.3d 957 (Ind. 2020).

210. Id. at 505 .

211. $I d$.

212. Id.

213. Id. at 505-06.

214. Id. at 507-08. 
of implied and express contract. ${ }^{215}$

Disagreeing with the trial court and the charter schools, the court of appeals held that the pre-2013 tuition funding statutes provided the schools with real-time tuition support for the then-current semester, based on school data from the previous September. ${ }^{216}$ The court rejected the schools' argument, and the trial court's finding, that the payments beginning in January were intended to be arrears payments for the school's first semester operations. ${ }^{217}$ Instead, it agreed with a 2002 Advisory Opinion from Indiana's Attorney General that the pre-2013 statutory scheme simply failed to provide charter schools with funding for their first semester of operations. ${ }^{218}$ The court acknowledged that its conclusion might "seem unfair" to the charter schools, but it reiterated that "[t]he General Assembly has the discretion to decide how to allocate State funds," and "regardless of whether the process and result are fair or unfair, it is solidly within the wheelhouse of the legislature to create a statewide budget and to decide how to fund charter schools, which are a creation of the General Assembly to begin with." 219

The court also rejected the charter schools' secondary argument that article 8 , section 1 of the Indiana Constitution - which requires the State to provide tuition-free education to children in Indiana-obligated the State to pay the charter schools for their first semester of operations. ${ }^{220}$ The court observed that "the Indiana Constitution does not confer a private right of action for monetary damages" and held that, in any event, because the State had at all times fulfilled its obligation under article 8 , section 1 by funding traditional public schools, "the State did not violate any constitutional obligations by structuring its charter school tuition funding in a way that required those schools to fund their own first semesters." 221

\section{ARTICLE 10, SECTION 1 - ASSESSMENT AND TAXATION}

In McClain Museum, Inc. v. Madison County Assessor, ${ }^{222}$ a military equipment museum appealed the Indiana Board of Tax Review's holding that the museum's real property did not qualify for (i) the educational purposes exemption, or (ii) the charitable purposes exemption during a particular tax year. The Indiana Tax Court reaffirmed the General Assembly's right, under article 10, section 1 of the Indiana Constitution, to "exempt certain categories of property

215. Id. at 508-09.

216. Id. at 509-10.

217. Id.

218. See id. at 510.

219. Id. at 510-11.

220. See id. at 511 .

221. Id.

222. McClain Museum, Inc. v. Madison Cty. Assessor, 134 N.E.3d 1096 (Ind. T.C. 2019), trans. denied, 145 N.E.3d 108 (Ind. 2020). 
from taxation." ${ }^{223}$ The court applied the statutes establishing the educational purposes and charitable purposes exemptions to hold that part of the museum's property qualified for the charitable purposes exemption, but none of the property qualified for the educational purposes exemption. ${ }^{224}$

As to the educational purposes exemption, the court observed that it is designed to encourage nongovernmental entities to "provide educational services for "the public welfare.""225 "[T] o qualify for [it], an applicant must show that through the use of its property it provides a benefit to the public sufficient to justify the loss in tax revenue. ${ }^{, 226}$ In order to invoke it, an applicant must show

that it provides the public with either the same educational training that would otherwise be furnished in Indiana's tax-supported schools or that it provides educational courses that are related to those found in taxsupported public schools, but not necessarily provided by them. ${ }^{227}$

Although it agreed that the museum's offerings might educate the public, it agreed with the Board that the museum did not qualify for the educational purposes exemption because it had not shown "that it conducts educational services, training, or coursework related to [military history] . . . [or reduces] the state's burden to provide military history education." ${ }^{228}$

Turning to the charitable purposes exemption, the court instructed:

[A] charitable purpose will be found to exist when " 1 ) there is evidence of relief of human want . . . manifested by obviously charitable acts different from the everyday purposes and activities of man in general; and 2) there is an expectation of a benefit that will inure to the public by the accomplishment of such acts." 229

It clarified that the term "charity" is "broadly construed" to mean "more than simply providing relief to the needy . . . . , but comprehends as well activities which are humanitarian in nature and rendered for the general improvement and betterment of mankind," such that a "purpose is charitable" if it provides a "social interest to the community as to justify permitting the property to be devoted to the purpose in perpetuity." ${ }^{230}$ A survey of the activities that the museum offered included: exhibits and displays for the general public to learn about "our

223. Id. at 1101-04.

224. Id. at 1101 .

225. Id. at 1102 (quoting Dep't of Local Gov't Fin. v. Roller Skating Rink Operators Ass'n, 853 N.E.2d 1262, 1265 (Ind. 2006)).

226. $I d$.

227. Id. (citing Roller Skating Rink Operators Ass' $n, 853$ N.E.2d at 1265).

228. Id.

229. Id. at 1103 (quoting Hamilton Cty. Assessor v. SPD Realty, LLC, 9 N.E.3d 773, 775 (Ind. T.C. 2014) (alteration in original)).

230. Id. at 1103-04 (quoting Coll. Corner, L.P. v. Dep't of Local Gov't Fin., 840 N.E.2d 905, 909 (Ind. T.C. 2006); State Bd. of Tax Comm'rs v. Methodist Home for Aged of Ind. Conference of Methodist Church, Inc., 241 N.E.2d 84, 89 (Ind. App. 1968)). 
country's military history and heritage"; and the ability to "view actual [military] equipment and understand how [it was] operated," "pay homage to its veterans and their families for the[ir] sacrifices"; and "access . . . its library of books and manuals for use in their own military research or restoration work." 231 The court found that the museum's offerings were "humanitarian in nature" because they "enhance[d] the public's knowledge and understanding . . . of the American experience . . . for the general improvement and betterment of mankind." 232 It therefore reversed the Board's finding and held that the portion of the museum property used for these charitable purposes qualified for the charitable purposes exemption. ${ }^{233}$

231. Id. at 1104 .

232. Id.

233. Id. at $1104-05$. 